http://jmscr.igmpublication.org/home/

ISSN (e)-2347-176x ISSN (p) 2455-0450

crossref DOI: https://dx.doi.org/10.18535/jmscr/v7i8.165

Journal Of Medical Science And Clinical Research

\title{
A Study of Current Trend of Sepsis Causative Organisms (Fungal and Bacterial) in Neonatal Blood Culture and their Drug Susceptibility Patterns at a Tertiary Care Hospital, Visakhapatnam, South India
}

\author{
Authors \\ Dr Rakesh Penta ${ }^{1}$, Dr Rajasri Jalla ${ }^{2}$, Dr Surya Bharathi Aripaka ${ }^{3}$ \\ ${ }^{1,2,3}$ Post Graduate, Department of Pediatrics, Andhra Medical College
}

\section{Background}

Sepsis is one of the major causes of morbidity and mortality in new borns. it is the clinical manifestation of systemic infection during the first 28 days of life. It is classified as early onset $(<72 \mathrm{hrs})$ and late onset $(>72 \mathrm{hrs})$ of sepsis. By knowing the current spectrum of pathogens causing sepsis and their drug sensitivity pattern most cases of neonatal sepsis can be saved by prescribing appropriate drugs before culture report collected. Antibiotics may be lifesaving for the few infants who are truly infected. However, broad spectrum antibiotics increase colonization with drug resistant organisms and injudicious use of antibiotics increases antimicrobial resistance. In a critically ill neonate with negative blood culture Fungal sepsis should be suspected. Although Candida albicans has historically been most frequently isolated with good response to flucanazole but now a day's non albicans candida have emerged as one of the common pathogen. This change in trend may be due to resistance of candida species to azoles .According to pooled hospital data based on NNPD(national neonatal perinatal data) survey, the incidence of neonatal sepsis is around 30/1000 live births and this incidence is 1 to 8 cases in 1000 live births in United States 1 .

\section{Materials and Methods}

This is a descriptive study carried out in the NICU, Dept of Pediatrics, Andhra medical college, King George hospital, Visakhapatnam between April 2018- April 2019 (1 year). This study includes all neonates aged 0-28 days of life with presumptive diagnosis of neonatal sepsis admitted in our NICU. Babies $>28$ days of life or with other serious complications are excluded from this study. Neonates with suspected sepsis were investigated as per standard protocol and blood samples were collected with proper antiseptic precautions and sent to microbiology department of our institute where they do follow standard scientific procedure for blood cultures. As it provides a definitive diagnosis for neonatal sepsis and should be taken before starting antimicrobial therapy ${ }^{3,4}$ Parameters related to blood cultures such as bacterial versus fungal, gram positive/gram negative sensitivity and resistance pattern to various antibiotics were recorded and statistical analysis was done regarding frequency and percentages and the results were presented in tabular representation ${ }^{5}$. 


\section{Results}

Out of 1600 suspected neonatal sepsis blood cultures, 880 blood cultures positive for bacteremia and 60 for fungi .among bacterial

\begin{tabular}{|l|c|c|}
\hline Organism Name & Number & Percentage \\
\hline E.coli & 289 & 32.9 \\
\hline Klebsiella & 264 & 30.1 \\
\hline Staph Aureus & 144 & 16.4 \\
\hline Pseudomonas & 83 & 9.5 \\
\hline CONS & 48 & 5.4 \\
\hline Proteus & 22 & 2.4 \\
\hline MRSA & 20 & 2.3 \\
\hline Acinetobacter & 10 & 1.1 \\
\hline TOTAL & 880 & $100 \%$ \\
\hline
\end{tabular}

Table 1: The common bacterial isolate in our study were E.coli (32.9\%), Klebsiella(30.1\%), Staphylococci Aureus (16.4\%) and others such as Pseudomonas (9.5\%),CONS (5.4\%), and proteus \& MRSA (2.3\%), Acinitobacter $(1.1 \%)$ organisms gram negative organisms accounts for $75.9 \%$ (668) and gram positive organisms are 24.1 $\%$ (212).

\begin{tabular}{|l|c|c|}
\hline $\begin{array}{l}\text { Organism } \\
\text { Name }\end{array}$ & Number & Percentage \\
\hline E.coli & 289 & 43.2 \\
\hline Klebsiella & 264 & 39.5 \\
\hline Pseudomonas & 83 & 12.5 \\
\hline Proteus & 22 & 3.2 \\
\hline Acinetobacter & 10 & 1.6 \\
\hline Total & 668 & $100(75.9 \%)$ \\
\hline
\end{tabular}

Table 2 : frequency of gram negative organisms isolated by blood culture of neonates with sepsis in the present study

\begin{tabular}{|l|c|c|}
\hline $\begin{array}{l}\text { Organism } \\
\text { Name }\end{array}$ & Number & Percentage \\
\hline Staph.aureus & 144 & 67.9 \\
\hline CONS & 48 & 22.6 \\
\hline MRSA & 20 & 9.43 \\
\hline Total & 212 & $100(24.1)$ \\
\hline
\end{tabular}

Table 3: frequency of gram positive organisms isolated by blood culture of neonates with sepsis in the present study

\begin{tabular}{|l|c|c|c|c|c|c|c|c|}
\hline $\begin{array}{l}\text { Antibiotic } \\
\text { Sensitivity/resi } \\
\text { stance }\end{array}$ & $\begin{array}{c}\text { E.coli } \\
\text { S/R }\end{array}$ & $\begin{array}{c}\text { Klebsie } \\
\text { lla } \\
\text { S/R }\end{array}$ & $\begin{array}{c}\text { Staph.a } \\
\text { ureus } \\
\text { S/R }\end{array}$ & $\begin{array}{c}\text { Pseudo } \\
\text { monas } \\
\text { S/R }\end{array}$ & $\begin{array}{c}\text { Proteus } \\
\text { S/R }\end{array}$ & $\begin{array}{c}\text { Acinetobac } \\
\text { ter } \\
\text { S/R }\end{array}$ & $\begin{array}{c}\text { CONS } \\
\text { S/R }\end{array}$ & $\begin{array}{c}\text { MRSA } \\
\text { S/R }\end{array}$ \\
\hline Ampicillin & $\mathbf{2 8 / 2 0 0}$ & $-/ 128$ & $22 / 48$ & $12 / 30$ & $3 / 9$ & $2 / 8$ & $10 / 24$ & $-/ 12$ \\
\hline Amoxicillin & $18 / 48$ & $-/ 100$ & $2 / 18$ & $-/ 12$ & $-/ 6$ & $-/ 3$ & $-/-$ & $-/ 10$ \\
\hline Amoxiclav & $20 / 60$ & $-/ 80$ & $-/-$ & $12 / 24$ & $-/ 8$ & $-/ 4$ & $-/ 16$ & $4 /-$ \\
\hline Amikacin & $-/-$ & $-/-$ & $-/-$ & $-/-$ & $-/-$ & $-/-$ & $-/ 12$ & $6 /-$ \\
\hline Azithromycin & $-/-$ & $30 /-$ & $58 /-$ & $-/-$ & $-/-$ & $-/-$ & $18 / 12$ & $12 /-$ \\
\hline Cefixime & $76 / 78$ & $\mathbf{1 1 0 / 3 6}$ & $24 / 14$ & $14 / 14$ & $-/-$ & $-/-$ & $-/-$ & $-/ 6$ \\
\hline Cefotoxime & $32 / 18$ & $2 / 36$ & $-/ 14$ & $14 /-$ & $-/-$ & $-/-$ & $-/-$ & $6 /-$ \\
\hline Ceftazidime & $118 / 62$ & $84 / 28$ & $18 /-$ & $24 / 12$ & $-/-$ & $-/-$ & $-/-$ & $-/-$ \\
\hline Cefoxitine & $-/-$ & $15 / 32$ & $54 / 42$ & $14 /-$ & $-/-$ & $-/-$ & $14 / 13$ & $8 /-$ \\
\hline Ceftriaxone & $21 / 20$ & $26 /-$ & $16 /-$ & $-/-$ & $-/-$ & $-/-$ & $-/ 12$ & $10 / 16$ \\
\hline Cefpodoxime & $10 / 40$ & $40 / 38$ & $-/ 24$ & $16 / 16$ & $-/ 6$ & $-/ 4$ & $-/ 16$ & $-/-$ \\
\hline $\begin{array}{l}\text { Cefperozone+s } \\
\text { ulbactam }\end{array}$ & $220 / 4$ & $142 / 3$ & $82 / 6$ & $68 / 6$ & $18 /-$ & $8 /-$ & $22 /-$ & $8 /-$ \\
\hline
\end{tabular}




\begin{tabular}{|l|c|c|c|c|c|c|c|c|}
\hline Cephalexin & $-/-$ & $18 / 22$ & $14 /-$ & $-/-$ & $-/-$ & $-/-$ & $-/-$ & $-/-$ \\
\hline Ciprofloxacin & $70 / 28$ & $-/ 24$ & $28 / 14$ & $12 /-$ & $-/-$ & $-/-$ & $-/-$ & $14 / 6$ \\
\hline cotrimoxazole & $18 / 22$ & $32 / 21$ & $-/-$ & $-/ 14$ & $-/-$ & $-/-$ & $-/ 12$ & $-/-$ \\
\hline Clindamycin & $-/-$ & $14 / 22$ & $18 / 32$ & $-/-$ & $-/-$ & $-/-$ & $-/-$ & $8 / 8$ \\
\hline Gentamycin & $190 / 8$ & $\mathbf{1 3 6 / 2 2}$ & $38 / 20$ & $62 /-$ & $14 /-$ & $9 /-$ & $20 /-$ & $-/ 12$ \\
\hline Imipenem & $74 / 10$ & $100 / 8$ & $22 /-$ & $24 /-$ & $10 /-$ & $4 /-$ & $10 /-$ & $12 /-$ \\
\hline levofloxacin & $-/-$ & $38 / 12$ & $-/-$ & $21 /-$ & $-/-$ & $-/-$ & $14 /-$ & $-/-$ \\
\hline Linezolid & $-/-$ & $-/-$ & $42 / 34$ & $-/-$ & $-/-$ & $-/-$ & $14 /-$ & $14 / 2$ \\
\hline Meropenem & $118 / 6$ & $52 /-$ & $24 /-$ & $22 /-$ & $10 /-$ & $4 /-$ & $-/-$ & $-/-$ \\
\hline Ofloxacin & $38 / 2$ & $48 / 24$ & $48 /-$ & $18 /-$ & $-/-$ & $-/-$ & $18 / 12$ & $10 /-$ \\
\hline $\begin{array}{l}\text { Piparacillin+ta } \\
\text { zobactem }\end{array}$ & $218 / 4$ & $48 / 18$ & $42 /-$ & $64 / 4$ & $16 /-$ & $8 /-$ & $14 /-$ & $8 /-$ \\
\hline Tetracycline & $-/-$ & $-/-$ & $78 / 4$ & $-/-$ & $-/-$ & $-/-$ & $18 / 10$ & $6 /-$ \\
\hline Tigecycline & $-/-$ & $-/-$ & $42 / 24$ & $-/-$ & $-/-$ & $-/-$ & $10 /-$ & $10 /-$ \\
\hline tiecoplanin & $-/-$ & $-/ 12$ & $70 / 12$ & $16 /-$ & $-/-$ & $-/-$ & $18 /-$ & $6 / 6$ \\
\hline tobramycin & $32 / 2$ & $28 / 14$ & $72 / 14$ & $12 /-$ & $-/-$ & $-/-$ & $20 /-$ & $8 / 2$ \\
\hline vancomycin & $-/-$ & $-/ 14$ & $94 / 4$ & $18 /-$ & $-/-$ & $-/-$ & $32 /-$ & $12 / 8$ \\
\hline
\end{tabular}

Table 4: shows antibiogram (sensitivity/resistance pattern) of all bacterial organisms.

\begin{tabular}{|l|c|c|c|}
\hline Antibiotics & Staph Aureus & CONS & MRSA \\
\hline Ampicillin & $22(15.2 \%)$ & $10(20.8 \%)$ & - \\
\hline Cefotoxime & - & - & $6(30.0 \%)$ \\
\hline Ceftazidime & $18(12.5 \%)$ & - & - \\
\hline Ceftriaxone & $16(11.1 \%)$ & - & $10(50.0 \%)$ \\
\hline Cefperazone+sulbactam & $82(56.9 \%)$ & $24(50.0 \%)$ & $8(40.0 \%)$ \\
\hline Ciprofloxacin & $28(19.4 \%)$ & - & $14(70.0 \%)$ \\
\hline Clindamycin & $18(12.5 \%)$ & - & $8(40.0 \%)$ \\
\hline Gentamycin & $38(26.3 \%)$ & $20(41.6 \%)$ & - \\
\hline Linezolid & $42(29.1 \%)$ & $14(29.1 \%)$ & $14(70.0 \%)$ \\
\hline Meropenem & $24(16.6 \%)$ & - & - \\
\hline Ofloxacin & $48(33.3 \%)$ & $18(37.5 \%)$ & $10(50.0 \%)$ \\
\hline Pipzo & $42(29.1 \%)$ & $14(29.1 \%)$ & $8(20.0 \%)$ \\
\hline Tigecycline & $42(29.1 \%)$ & $10(20.8 \%)$ & $10(50.0 \%)$ \\
\hline Tiecoplanin & $70(48.6 \%)$ & $18(37.5 \%)$ & $6(30.0 \%)$ \\
\hline $\begin{array}{l}\text { Vancomycin } \\
\text { Table 5: Shows antibiotic sensitivity pattern among gram positive bacterial isolates in the } \\
\text { present study .65.2\%(94/144), 56.9\%(82/144) and 48.6\%(70/144) of Staph Aureus isolates } \\
\text { were found sensitive to Vancomycin, Cefperazone+Sulbactam and Tiecoplanin respectively } \\
\text { about 70\%MRSA strains were sensitive to Linezolid and Ofloxacin and 79.1\% CONS were } \\
\text { found to be sensitive to Vancomycin. }\end{array}$ \\
\hline
\end{tabular}




\begin{tabular}{|l|l|l|l|}
\hline Antibiotics & Staph aureus & CONS & MRSA \\
\hline Ampicillin & $48(33.3 \%)$ & $24(50.0 \%)$ & $12(60.0 \%)$ \\
\hline Cefotoxime & $14(9.7 \%)$ & - & - \\
\hline Ceftazidime & - & - & - \\
\hline Ceftriaxone & - & $12(25.1 \%)$ & $16(80.0 \%)$ \\
\hline Cefperazone+sulbactam & $6(4.1 \%)$ & - & - \\
\hline Ciprofloxacin & $14(9.7 \%)$ & - & $6(30.0 \%)$ \\
\hline Clindamycin & $32(22.2 \%)$ & - & $8(40.0 \%)$ \\
\hline Gentamycin & $20(13.8 \%)$ & - & $12(60.0 \%)$ \\
\hline Linezolid & $32(22.2 \%)$ & - & $2(10.0 \%)$ \\
\hline Meropenem & - & - & - \\
\hline Ofloxacin & - & $12(25.1 \%)$ & - \\
\hline Pipzo & - & - & - \\
\hline Tigecycline & $24(16.6 \%)$ & - & - \\
\hline Tiecoplanin & $12(8.3 \%)$ & - & $6(30.0 \%)$ \\
\hline Vancomycin & $4(2.7 \%)$ & - & $8(40.0 \%)$ \\
\hline $\begin{array}{l}\text { Table 6: Shows antibiotic } \\
\text { present study 33.3\% of Staph Aureus, 60\% MRSA were found to be resistance to Ampicillin } \\
\text { and 40\% of MRSA found be resistance even to Vancomycin also. }\end{array}$ \\
\hline
\end{tabular}

\begin{tabular}{|c|c|c|c|c|c|}
\hline Antibiotics & E.Coli & Klebsiella & Psudomonas & Proteus & Acinetobacter \\
\hline Ampicillin & $28(9.6 \%)$ & - & $12(14.4 \%)$ & $3(13.6 \%)$ & $2(20.0 \%)$ \\
\hline cefotoxime & $32(11.0 \%)$ & $2(0.7 \%)$ & $14(16.8 \%)$ & - & - \\
\hline ceftizidime & $118(40.8 \%)$ & $84(31.8 \%)$ & $24(28.9 \%)$ & - & - \\
\hline ceftriaxone & $21(7.2 \%)$ & $26(9.8 \%)$ & - & - & - \\
\hline ciprofloxacin & $70(24.2 \%)$ & $28(10.6 \%)$ & $12(14.4 \%)$ & - & - \\
\hline $\begin{array}{l}\text { Cefperazone+ } \\
\text { sulbactam }\end{array}$ & $220(76.1 \%)$ & $142(53.7 \%)$ & $68(81.9 \%)$ & $18(81.8 \%)$ & $8(80.0 \%)$ \\
\hline Clindamycin & - & $18(6.8 \%)$ & - & - & - \\
\hline Gentamycin & $190(65.7 \%)$ & $136(51.5 \%)$ & $62(74.6 \%)$ & $14(63.6 \%)$ & $9(90.0 \%)$ \\
\hline Linezolid & - & $42(15.9 \%)$ & - & - & - \\
\hline Meropenem & $118(40.8 \%)$ & $52(19.6 \%)$ & $22(26.5 \%)$ & $10(45.4 \%)$ & $4(40.0 \%)$ \\
\hline Ofloxacin & $38(13.1 \%)$ & $48(18.1 \%)$ & $18(21.6 \%)$ & - & - \\
\hline Pipzo & $218(75.4 \%)$ & $48(18.1 \%)$ & $64(77.1 \%)$ & $16(72.7 \%)$ & $8(80.0 \%)$ \\
\hline Tigecycline & - & - & - & - & - \\
\hline Ticoplanin & - & - & $16(19.2 \%)$ & - & - \\
\hline Tobramycin & $32(11.0 \%)$ & $28(10.6 \%)$ & $12(14.4 \%)$ & - & - \\
\hline Vancomycin & - & - & $18(21.6 \%)$ & - & - \\
\hline \multicolumn{6}{|c|}{$\begin{array}{l}\text { Table 7: Shows antibiotic sensitivity pattern among gram negative bacterial isolates in the } \\
\text { present study. Cefperazone and Sulbactam, Piperacillin /Tazobactem and Gentamycin were } \\
\text { the three most effective antibiotics for all gram negative organisms mentioned in the present } \\
\text { study. }\end{array}$} \\
\hline
\end{tabular}




\begin{tabular}{|c|c|c|c|c|c|}
\hline Antibiotics & E.coli & Klebsiella & Pseudomonas & Proteus & Acinetobacter \\
\hline Ampicillin & $200(69.2 \%)$ & $128(48.4 \%)$ & $30(36.1 \%)$ & $9(40.9 \%)$ & $8(80.0 \%)$ \\
\hline cefotoxime & $150(51.9 \%)$ & $88(33.3 \%)$ & - & - & - \\
\hline ceftizidime & $62(21.4 \%)$ & $28(10.6 \%)$ & $12(14.4 \%)$ & - & - \\
\hline ceftriaxone & $98(33.9 \%)$ & $82(31.0 \%)$ & - & - & - \\
\hline ciprofloxacin & $28(9.6 \%)$ & $14(5.3 \%)$ & - & - & - \\
\hline $\begin{array}{l}\text { Cefperazone+ } \\
\text { sulbactam }\end{array}$ & $4(1.3 \%)$ & $3(1.1 \%)$ & $6(7.2 \%)$ & - & - \\
\hline Clindamycin & - & $32(12.1 \%)$ & - & - & - \\
\hline Gentamycin & $8(2.7 \%)$ & $22(8.3 \%)$ & - & - & - \\
\hline Linezolid & - & $34(12.8 \%)$ & - & - & - \\
\hline Meropenem & $6(2.05 \%)$ & - & - & - & - \\
\hline Ofloxacin & $2(0.6 \%)$ & $24(9.09 \%)$ & - & - & - \\
\hline Pipzo & $4(1.3 \%)$ & $18(6.8 \%)$ & $4(4.8 \%)$ & - & - \\
\hline Tigecycline & - & - & - & - & - \\
\hline Ticoplanin & - & $12(4.5 \%)$ & - & - & - \\
\hline Tobramycin & $2(0.6 \%)$ & $14(5.3 \%)$ & - & - & - \\
\hline Vancomycin & - & $14(5.3 \%)$ & - & - & - \\
\hline
\end{tabular}

\begin{tabular}{|l|c|c|}
\hline Organism & No of isolates & Percentage \\
\hline Candida.albicans & 33 & $55.1 \%$ \\
\hline Candida.parapselosis & 14 & $24.4 \%$ \\
\hline Candida. glabrata & 10 & $16.3 \%$ \\
\hline Candida.tropicalis & 2 & $4.0 \%$ \\
\hline others & 1 & \\
\hline $\begin{array}{l}\text { Table 9: Shows characterization of various fungal } \\
\text { species isolated from blood culture }\end{array}$ \\
\hline
\end{tabular}

\begin{tabular}{|l|l|l|l|}
\hline Organism & Amphotericin & Flucanazole & Isolates \\
\hline Candida.albicans & $31(96.2 \%)$ & $26(81.4 \%)$ & 33 \\
\hline Candida.parapselosis & $14(100 \%)$ & $12(83.3 \%)$ & 14 \\
\hline Candida. glabrata & $9(93 \%)$ & $3(25.0 \%)$ & 10 \\
\hline Candida.tropicalis & $2(100 \%)$ & $1(50.0 \%)$ & 2 \\
\hline \multicolumn{2}{|l|}{ Table 10: Shows antifungal suspceptability of candida isolates } \\
\hline
\end{tabular}

\section{Discussion}

Emergence of increased antimicrobial resistance is due to Lacking of health system based ongoing surveillance of infections and tracking of antimicrobial resistance, information provided in the current paper will help practitioners stay vigilant for any change and institute appropriate practice modalities. Removal of antibiotic from the therapeutic regimen may lead to reversal of microbial resistance into susceptible phenomena have been described in the literature with serious public health ramifications as one study 
mentioned that chloroquine once again became highly effacaious in Malawi,12 years after it was withdrawn from use because of rate of treatment failures in more than $50 \%$ cases.in the context of worldwide threat of microbial resistance our country condition is considered more stark than any other place. Most newborn units in our country are facing the problem of overwhelming resistance to all antibiotics particularly to cephalosporins ${ }^{4}$ Antimicrobial therapy can be made specific on positive culture and sensitivity reports. However, this would be known only after two to three days in a best institutions Hence every treating unit should adapt a suitable policy based on spectrum of etiological agent and drug sensitivity and must be periodically reviewd and modified.

During the study period, out of 1600 newborn babies who had been primarily diagnosed as neonatal sepsis, culture confirmed sepsis $(880 / 1600)$ are bacterial and (60/1600) are fungal. Out of 880 bacterial organisms isolated,75.9\% $(668 / 880)$ were gram negative and $24.1 \%$ $(212 / 880)$ were gram positive which was in agreement with vaniya HV vd al study ${ }^{6}(51 \%)$, shrestha et al $\operatorname{study}^{7}(44 \%)$, shahian at al study ${ }^{8}$ $(43 \%)$ and thakur s at al study ${ }^{9}(42 \%)$. Where as in meher at al study ${ }^{1}$, they found culture positivity in $22.1 \%$ cases and jyothi $\mathrm{p}$ et $\mathrm{al}^{16}$ found $92 \%$ culture positivity. in our study out of 1600 newborns suspected neonatal sepsis, $1136(71 \%)$ are outborn, $464(29 \%)$ are inborn which was in agreement with shamiya NK et al study ${ }^{7}$ (outborn-75\%, inborn$25 \%)$.

In our study, predominance of gram negative organisms is comparable with studies reported by Rahman ${ }^{17}$ et al most common pathogen isolated is E.coli (32.9\%), klebsiella(30.1\%), staph aureus (16.4\%) and pseudomonas(9.5\%) but klebsiella was the predominant organism isolated in neonatal sepsis in studies reported by Vaniya $\mathrm{HV}^{6}$ et al, Shrestha ${ }^{7}$ et al, Jyothi ${ }^{15}$ et al and Aletaveb ${ }^{18}$ et al. whereas pseudomonas and staph aureus were the predominant isolate in studies done by Bhet $^{19}$ et al and Shahian ${ }^{7}$ et al.
The analysis of antibiogram of our study revealed decreased sensitivity among gram negative isolates against commonly used antibiotics such as ampicillin, amoxicillin, amoxyclav and cefotaxime and ceftriaxone. This finding was in agreement with vaniya ${ }^{6}$ et al study.

Gram negative isolates in our study were found most sensitive to cefperazone+salbactum, piperacillin+tazobactum and to gentamicin. This is in contrary to vaniya et al study where these isolates were most sensitive to ciprofloxacin and oflaxacin.

Gram positive organisms are most sensitive to tobramyin, vancomycin, cefperazone+salbactum where as MRSA isolates of our study were found most sensitive to ofloxacin, linezolid, vancomycin and tigecycline in jyothi ${ }^{15}$ et al and vaniya ${ }^{6}$ et al studies, found that gram positive isolates are most sensitive to linezolid.

In our study, we found overall very few isolates were sensitive to cefotaxime, ampicillin, amoxyclav and ceftriaxone. Among 60 fungal isolates, 33 are found to be candida albicans $(55.1 \%)$ and remaining $44.9 \%$ are non-candida albicans, this was in comparison to study conducted by Agarwal ${ }^{12}$ et al(13.6\%) and Rani et al $(11 \%)^{13}$.

Combination of various risk factors (prematurity, low birth weight, prolonged antibiotic use, ventilator support and total parental nutrition) is known to be strongly associated with development of candidiasis ${ }^{11}$. Most of the fungal isolates are sensitive to amphotericin B compared to flucanazole $^{14}$. This substantiates the need of prophylactic antifungal used in a setup where continuous upsurge in the incidence of fungal infection $^{10}$.

\section{Conclusion}

This study revealed gram negative organisms constituted major cause of neonatal sepsis and most of the organisms are resistant to commonly used antibiotics such as ampicillin, cefotaxime and ceftriaxone. Even for vancomycin at the same time in fungal isolates there was good correlation 
between the virulence traits and antifungal agent flucanazole, so amphotericin B or newer azoles (voriconazole) are better alternatives ${ }^{14}$. Therefore we suggest an appropriate drug policy should be formulated in the hospital depending upon the antibiogram pattern. Unnecessary or excessive use of antibiotics should be discouraged at all levels. Institute should implement a surveillance program on antibiotic resistance. It is recommended to sensitize local hospitals regarding the common isolates and their drug sensitivity pattern to prevent emergence of drug resistance.

\section{References}

1. Mehar V, Yadav D,Somani P et al neonatal sepsis in a teritiary care centre in Central India, Neontal perinatal Med 2013; 6(2):165-72.

2. Lukas SL Schoendorf KC, Schuchat A. Trends in sepsis related neonatal mortality in the United States,1985-1998.Pediatr Infect Dis J 2004;23(7):599-603.

3. Sankar MJ, Agarwal R, Deorari AK, et al. Sepsis in the newborn. Indian $\mathrm{J}$ Pediatr 2008;75(3):261-6.

4. Ghai OP, Paul VK, Bagga A, et al. Essential paediatrics. $9^{\text {th }}$ edn. New Delhi, CBS Publishers, 2014;8:162-5.

5. Joshi S. Hospital antibiogram: a necessity. Indian J Med Microbiol 2010;28(4):277-80.

6. Vaniya HV, Patel NM, Agarwal JM, et al. Antimicrobial culture sensitivity pattern in neonatal sepsis in a tertiary care hospital. Int J Med Sci Public Health2016;5(4):277-80.

7. Shrestha S, Shrestha NC, Dongal SS, et al. Bacterial isolates and its antibiotic suseptability pattern in NICU. Kathmandu Univ Med J 2013;11(41):66-70.

8. Shahian M, Pishva N, Kalani M. Bacterial etiology and antibiotic sensitivity patterns of early-late onset neonatal sepsis among newbornsin Shiraz, Iran 2004-2007.IJMS 2010;35(4):293-8.

9. Thakur S, Sood A, Thakur K, et al. Bacteriological profile of neonatal septicemia in a rural tertiary care hospital in North India. Indian J Med Micobiol 2016;34(1):67-71.

10. Benjamin DK, Stoll BJ, Fanaroff AA. Neonatal candidiasis, risk factors at 18-22 months, Pediatr,2006;117(1):84-92.

11. Baley JE. Neonatal candidiasis: the current challenge. Clin Perinatol.1991;18(2)263-80.

12. Agarwal J, Bansal S, Malik GK, Jain A. Trends in neonatal septicemia: emergence of non albicans candida. Indian Pediatr 2004;41:712-5.

13. Rani R, Mohapatra NP, Mehta G, Randhawa VS. Changing trends of Candida species in neonatal septicemia in a tertiary north Indian hospital. Indian $\mathbf{J}$ Med Microbiol.2002;20:42-4.

14. Egyptian journal of medical microbiology, April 2008.

15. Jyothi P Basava Raju MC, Basava raju PV. Bacteriological profile of neonatal septicemiaand antibiotic susceptabilty pattern of isolates. J Nat Sci Biol Med 2013;4(2):306-9.

16. Khan SN, Joseph S.Neonatl sepsis: Antibiotic sensitivity and resistance pattern of commonly isolated pathogens in NICU, South India. Int $\mathrm{J}$ Pharma Bio Sci 2012:3(4)802-9.

17. Rahman S, Hameed A, Roghani MT, et al. Multidrug resistant neonatal sepsis in Peshwar, Pakistan. Arch Dis Child Fetal Neonatal Ed 2002;87(1):F52-4.

18. Aletayeb SMH, Khosravi AD, Dehdashtian $\mathrm{M}$, et al. Identification of bacterial agents and antimicrobial susceptibility of neonatal sepsis: a 54 month study in a tertiary hospital. Afr Microbiol Res 2011;5(5):52831.

19. Bhat YR, Lewis LE, Vandana KE. Bacterial isolates of early-onset neonatal sepsis and their antibiotic susceptibility pattern between 1998 and 2004: an audit from a center in India. Ital J Pediatr 2011;37:32. 